\title{
JUDEUS, CATÓLICOS E PROTESTANTES NA TERRA DO AÇUCAR: AFINIDADES E DIVERGÊNCIAS
}

Jews, catholics and protestants in the land of sugar: affinities and divergencies

Elizete da Silva ${ }^{1}$

\begin{abstract}
"Não existe se na História. Existe foi. Mas, o se nos persegue." Luís Henrique Dias Tavares
\end{abstract}

\section{RESUMO}

A Igreja Católica era hegemônica no período colonial na América Portuguesa, porém outras confissões religiosas também constituíam o campo religioso, a exemplo do Judaísmo, o Protestantismo, as Religiões Xamânicas Indígenas e as Religiões de Matrizes Africanas, condenadas como heresias, feitiçarias, passíveis de perseguição pela Inquisição. A Igreja Católica era o inimigo comum de judeus e protestantes, os quais mantinham afinidades e redes de sociabilidade, que contemplavam negócios e a leitura de textos sagrados. Com a dominação holandesa no Nordeste, especialmente no período de Nassau, houve uma certa tolerância religiosa, vigiada pelos clérigos calvinistas, ciosos de suas doutrinas.

Palavras chave: América Portuguesa. Cristãos-Novos. Protestantismo. Redes de solidariedade.

\begin{abstract}
The Catholic Church was hegemonic in the colonial times in Portuguese-America, but other religious denominations also constituted the religious field, such as Judaism, Protestantism, Indigenous Shamanic Religions and African Religions, all condemned as heresies, witchcraft, subject to persecution by the Inquisition. The Catholic Church was the common enemy of Jews and Protestants, who maintained affinities and networks of sociability, which contemplated business and the reading of Sacred Texts. With the Dutch domination in the Northeast, especially, at Nassau's time, there was a certain religious tolerance, watched over by the Calvinist clerics, who were jealous of their doctrines.
\end{abstract}

Key words: Portuguese-America. New Christians. Protestantism. Solidarity network.

\section{INTRODUÇÃO}

Resultante de um projeto de pesquisa mais amplo, neste artigo, pretendemos analisar as redes de sociabilidade e solidariedade entre judeus, cristãos-novos e protestantes na América Portuguesa no século XVI e XVII. A historiografia colonial raramente tem tratado das religiões

\footnotetext{
${ }^{1}$ Programa de Pós-Graduação em História, Universidade Estadual de Feira de Santana (UEFS), Feira de Santana, BA, Brasil E-mail: cliosilva@yahoo.com.br Este artigo é dedicado ao Professor de História do Brasil, Luís Henrique Dias Tavares, falecido no dia 22 de junho. Instigou-nos a pesquisar o Brasil holandês e respondeu aos nossos questionamentos com este texto da epigrafe.

REVISTARELEGENSTHRÉSKEIA - 2020 - UFPR
} 
que construíram a cultura brasileira, tampouco dos intercursos religiosos e da presença protestante. Abordamos os primeiros séculos da colonização, o período designado como Brasil holandês (1630-1654), quando se estreitaram essas relações, com a permissão de funcionamento de sinagogas e cemitérios judaicos pela Companhia das Índias Ocidentais, de orientação calvinista.

O Regimento de 1548 do Primeiro Governador Thomé de Souza rezava que as Terras Brasilis foram cultivadas para o "proveito do reino e dilatação da fé católica”. Em 1555 ocorreu a criação, em Salvador, do primeiro arcebispado com D. Pero Fernandes Sardinha. Constituíam o campo religioso o Catolicismo, o Judaísmo, o Protestantismo, as Religiões Xamânicas Indígenas e Religiões de Matrizes Africanas, condenadas como heresias, feitiçarias, pelo Tribunal do Santo Ofício.

O Judaísmo é uma religião abraâmica, semita, monoteísta, não admitindo outros deuses, além de Yahaveh. Moisés, (século XIV A. C.) o sistematizador do monoteísmo hebraico, recebeu a revelação de Yahaveh, como o verdadeiro Deus do povo de Israel numa sarça ardente, conforme relato bíblico de Gênesis. Com características étnicas e guerreiras, a divindade hebraica era o Senhor dos Exércitos do Velho Testamento. A Torah ou Torá é o livro sagrado dos judeus. Já na Antiguidade romana, as perseguições manifestavam-se: o mandamento "não terás outros deuses diante de mim, o símbolo da eleição, isto é, a prática da circuncisão, deveria suscitar nos espíritos ressonâncias perturbadoras" (POLIAKOV,1979, p.6,7).

Durante a Idade Média os judeus foram perseguidos pela Igreja Católica, pois eram considerados deicidas pelo fato de terem crucificado a Jesus Cristo, além de acusados de crimes e infanticídio ritual (POLIAKOV, 1979). A Peste Negra (1347-1350), que ceifou mais de um terço da população da Europa, foi colocada a culpa nos judeus, os hereges que deveriam morrer a bem da cristandade, os quais fugindo das perseguições migraram para várias regiões europeias, especialmente os Países Baixos e no início dos tempos modernos também se deslocaram para as colônias da América.

Cristãos-novos, em referência aos cristãos tradicionais, é a designação para os judeus de origem ibérica, que se converteram ao Cristianismo e tornaram-se seguidores da Igreja Católica. Muitas famílias de cristãos-novos migraram para o Novo Mundo. Segundo Novinsky não escaparam de sua judeidade: "viviam uma condição da qual não podiam fugir. Quisessem ou não eram considerados judeus e suspeitos, mesmo rejeitando seu sistema de crenças" (NOVINSKY, 2019, p. 21). Preferencialmente suspeitos de heresia pela hierarquia eclesiástica. 
O Protestantismo é um ramo do Cristianismo, religião que se organiza a partir da atuação de Jesus Cristo, uma figura histórica que viveu no século I. O Cristianismo nasceu no seio do Judaísmo, se apropriou de doutrinas e rituais da religião abraâmica. Após perseguições foi oficializado no século IV d.C. como a religião do Império Romano, tornando-se hegemônico na Idade Média como Igreja Católica, a qual decorrente do Cisma do Oriente, subdividiu-se no século XI, em Igreja Ortodoxa e no século XVI, com a Reforma Protestante. Há vários grupos reformados, seguidores dos princípios básicos: a salvação pela fé, a Bíblia como regra de fé e o sacerdócio universal (SILVA,2017). Trataremos, especialmente, de luteranos e calvinistas.

Heresia, segundo o Manual dos Inquisidores, reeditado em 1578 pelos dominicanos é: "toda proposição que se oponha a tudo o que a Igreja tenha proposto à fé dos fieis" (EYMERICH, 1961, p. 15). Ortodoxos são aqueles que tiveram poder político para impor suas definições. "Ortodoxia, contém sempre as ideias dos mais fortes. Heresia, indica as ideias dos mais fracos" (ALVES, 1979).

Trabalhamos na perspectiva da História Cultural e da História das Religiões. Conceitos de representação, apropriação e ressignificação de Chartier (2002) permitem analisar as operações discursivas que aproximam o Judaísmo do Protestantismo. As "afinidades eletivas" entre a ética calvinista e o sucesso nas atividades capitalistas encontrariam similaridades entre judeus que se dedicaram as atividades mercantis no período, "uma espécie de vocação, um significado religioso ao trabalho secular cotidiano" (WEBER, 1967, p. 53).

\section{ENTRE APROXIMAÇÕES E QUERELAS TEOLÓGICAS}

Após a Peste Negra as perseguições contra a população judaica se agravaram no continente europeu, especialmente, na Península Ibérica. Expulsos da Espanha, no final do século XV, muitos judeus sefarditas migraram para Portugal, em busca de refúgio na judiaria lusitana ou se convertendo ao Catolicismo. Pressionado pela corte vizinha, em 1497 D. Manoel obrigou por decreto a conversão da população judaica impondo aos judeus a fé católica ou a fuga de Portugal, eis a origem do cristão-novo, "a simples adoção do Catolicismo abria aos judeus todas as vantagens que se asseguravam aos cristãos velhos" (NOVINSKY, 1972, p. 37).

Abriram-se vantagens jurídicas, no entanto os cristãos-novos “continuaram a viver e a conviver entre si, separados dos cristãos velhos, até como forma de defesa da crescente espionite por parte destes que viam numa qualquer diferença a marca da apostasia" (MEA, 2019, p. 30). Os conflitos persistiram entre os novos e os velhos cristãos: em 1505, a Sinagoga 
de Évora foi destruída, livros e objetos rituais. Em abril de 1506, a seca, fome e peste que assolavam Lisboa foram identificadas como castigo e os culpados eram os judeus: mais de mil cristãos-novos foram massacrados, mortos a pauladas.

Resultante de fatores religiosos, econômicos e políticos em 1517, o monge Martinho Lutero liderou um movimento de ruptura na religião Cristã, o qual preconizava a volta aos princípios bíblicos, a salvação pela graça de Cristo, o sacerdócio universal dos cristãos e contestava a autoridade papal. "A Reforma Protestante foi uma cisão na cristandade em dois blocos: a Igreja Católica liderada pelo Papa e o Protestantismo, subdividido em diversos grupos" (SILVA, 2017, p. 25). As disputas teológicas e as guerras religiosas na Europa atravessaram o século. A Reforma expandiu-se nos Países Baixos, os quais viviam os problemas religiosos, acrescidos das disputas políticas. O Protestantismo nas províncias neerlandesas foi hegemonizada pelo calvinismo, do qual "o mais profundo efeito foi espraiar uma mentalidade protestante e minar a Igreja Católica estabelecida” (ISRAEL, 1998, p. 74).

O movimento reformador provocou transformações culturais e políticas na Europa, com desdobramentos na América. Na bula Licet Abinitio do Papa Paulo III, a heresia protestante era o alvo do Santo Oficio (BETHENCOURT,2000). Com o movimento reformista, a Inquisição recrudesceu, especialmente nos países ibéricos, onde as suspeitas de heresia dos "Luteros" tornaram-se corriqueiras em Portugal. Em 1571, o humanista e embaixador, nos Países Baixos, Damião de Góes, foi preso pela Inquisição lusitana por crime de luteranismo (REGO,2007).

No século XVI, o Ocidente vivia a triangularização entre judeus, protestantes e católicos. As concepções protestantes sobre o Judaísmo variaram ao longo do período. Lutero e Calvino, inicialmente, concebiam os judeus como o Israel Bíblico e os mesmos se converteriam às doutrinas reformadas, que eram, segundo eles, um retorno ao Cristianismo Primitivo. Posteriormente, Lutero manteve a concepção católica, que os judeus eram deicidas, portanto mereciam castigo pelo crime de matar a Jesus e afirmava que o Papa era a besta do Apocalipse. Para Calvino, os judeus não passavam de heréticos, pois não aceitavam o Messias.

No que pese as divergências teológicas dos líderes reformados com o Judaísmo havia uma afinidade eletiva, que aproximava protestantes e judeus, a partir das convergências de seus livros sagrados. Calvino reconheceu na lei mosaica e nos profetas judaicos a continuidade dos planos divinos “ o propósito de Moisés e de todos profetas foi ensinar o modo de reconciliação entre Deus e os homens (donde Paulo também chama a Cristo de fim da Lei. (Rom. 10,14)" (CALVINO, 1958). A diáspora sefardita para os Países Baixos permitiu uma aproximação intelectual entre humanistas e religiosos, "tornaram-se comuns a correspondência e os REVISTARELEGENSTHRÉSKEIA - 2020 - UFPR 
encontros entre homens instruídos cristãos e judeus. Essas conversações amistosas e polêmicas eram fomentadas por um mundo conceitual fundado em filosofia, teologia e cultura geral" (KAPLAN,2000, p.398).

Por outro lado, a Inquisição e a oposição ao Catolicismo aproximava judeus e protestantes. Para Lutero a estrutura católica se assemelhava ao Cativeiro Babilônico, título de um livro que o reformador escreveu em 1520. "Calvino exprimia concepções negativas sobre a Igreja Católica e sua pretensão de garantir a pureza doutrinária de forma monolítica e com instrumento de violência" (SILVA, 2019 p. 130). Nas Instituições da Religião Cristã, se referiu aos que espalhavam "raiva e furor no reino" como "ímpios que não dão lugar algum à verdadeira doutrina... adversários que espalham fogo e sangue" (CALVINO, 1958, p. 76). Segundo o reformador, a doutrina que pregavam era injustamente vista pelos adversários ao dizerem que seus seguidores "devem ser castigados com cárcere, desterros, confisco de bens e fogo e que deve ser eliminada do mundo" (CALVINO, 1958, p. 76).

Em 1571, a anabatista Anne Hendriks foi queimada na fogueira pela Inquisição Espanhola, acusada de heresia. O seu martírio ocorreu em Amsterdam e foi representado pelo artista Jan Luyken (1649-1712), no seu trabalho Religious Persecutions. Na Biblioteca da Universidade de Leiden há um livro com desenhos e pinturas, de autoria de Cornelis Brouvez, sobre a Inquisição Espanhola, datado de 1556, retratando autos de fé, pessoas queimadas nas fogueiras, com fortes críticas a tirania Católica do Papa, o Rei de Espanha e o Duque de Alba pisoteando os protestantes holandeses.

Do ponto de vista da Igreja Católica, o Judaísmo e o Protestantismo eram heresias a combater. Segundo o Padre Vieira, que viveu no Brasil no século XVII, os protestantes representavam o cavalo vermelho do Apocalipse, Equus Rusus; "o cavallo ruyvo significa os Hereges, cor das gentes do Norte \& Setentrionaes, onde reyna a heregia, \& lhe quadra igualmente bem a insignia do montante por ser ella a origem $\&$ fomento de todas as guerras da Christandade" (VIEIRA, 1957, p. 6- 8).

Países de tradição Protestante como a Holanda e a Inglaterra tornaram-se locais de refúgio e acolhida para os judeus perseguidos pelo Santo Oficio. O Rabino Menasseh Ben Israel, Manoel Soeiro, um judeu português que liderou a Sinagoga Portuguesa de Amsterdam, escreveu um instigante texto intitulado a Origem dos Americanos e a Esperança de Israel, publicado, em Amsterdam, em 1641. No prefácio está registrado: “Depois de ter sido em sua juventude castigado três vezes pela Inquisição, se retirou para Amsterdã com sua mulher Raquel Soeiro e família " (ISRAEL,1881, p. 3). No século XVII, em Amsterdam, muitos cristãos-novos REVISTARELEGENSTHRÉSKEIA - 2020 - UFPR 
retornaram ao Judaísmo, a exemplo de Isaac Oróbio de Castro, que se tornou um grande polemista em defesa da "superioridade do judaísmo que eles consideravam a única interpretação válida de Lei divina " (KAPLAN,2000, p.253).

\section{RECOMPONDO IDENTIDADES EM TERRITÓRIO CATÓLICO}

A diáspora para o Novo Mundo era uma alternativa para os sefarditas. Os que se dedicavam ao comércio refizeram suas rotas. O Brasil poderia ser uma possibilidade de refazer laços identitários e com as forças sagradas para cristãos-novos, que tinham se convertido, obrigados pelo decreto real. "A fuga dos portugueses cristãos-novos para o Brasil era mais fácil do que para qualquer lugar da Europa. Muitos conseguiram embarcar clandestinamente para o Novo Mundo, considerado a Terra Prometida” (NOVINSKY, 2009, p. 26).

Na primeira década do século XVI, A Terra de Santa Cruz tornou-se a Terra Brasilis, na qual abundava o pau-brasil ou ibirapitanga, como os habitantes da terra designavam a madeira vermelha, cobiçada pelos europeus, perfeita para a indústria naval e têxtil. O primeiro consórcio explorador de pau brasil na América Portuguesa foi liderado pelo cristão-novo Fernando de Noronha, o qual sediou feitoria em Pernambuco. O Rei garantia o monopólio e concedia a exploração da madeira e pagamento do dízimo, uma divisão dos lucros. Cristãosnovos participaram dos empreendimentos coloniais nas terras brasílicas desde a primeira hora.

Fugindo das guerras religiosas na França, huguenotes amalgamaram os interesses mercantis com a busca de refúgio religioso. Os primeiros cultos protestantes na Colônia datam de 1555, na comunidade que Nicolau Villeghanon fundou na Guanabara, adotando a Confissão de Fé da Guanabara, "calvinista: salvação pela fé e predestinação divina para a salvação ou perdição do homem " (CRESPIN 1917, p. 47). Conforme Lery (1980), os huguenotes franceses buscavam um lugar seguro para viverem o Evangelho. Villeghanon solicitou à Calvino a vinda de pastores para a França Antártica. "Os pastores calvinistas, juntamente com Lery, assistiam religiosamente os franceses, bem como encetaram a catequese dos indígenas do Rio de Janeiro, com o propósito de converte-los para as doutrinas reformadas" (SILVA, 2017, p. 90). Com a expulsão dos franceses (1566), desorganizou-se a comunidade reformada. A Igreja Católica reassegurou o monopólio da fé no território brasílico.

A atividade açucareira foi a principal fonte de renda da América Portuguesa: "o Brasil dominou o mercado europeu de açúcar. Em fins do século XVI, o número de engenhos na Bahia e em Pernambuco aumentou rapidamente, valendo-se dos solos férteis, de um clima favorável 
e de um grande número de escravos" (SCHWARTZ,2002, p. 23). A Bahia colonial, sede do governo metropolitano tinha uma economia exportadora, um intenso comércio triangular de açúcar, tabaco, madeira e drogas do sertão, que eram comercializados especialmente por cristãos-novos sefarditas com os Países Baixos, França e Inglaterra, e a intermediação de Portugal. O interesse dos flamengos pelo domínio das terras do açúcar justificava-se pelo seu valor de troca na Europa. (STRUM, 2012). Cristãos-novos residentes na Bahia, a exemplo da família Lopes, da família Ribeiro, dentre outras, montaram grandes redes de negócios entre o Brasil e os Países Baixos. Nos arquivos notariais de Amsterdam, encontram-se assentamentos de contratos de navios que faziam o comércio com a América Portuguesa, desde 1605.

A relação entre Amsterdã e Lisboa era assegurada pela participação sefardita no comércio entre estas cidades. A diáspora associada a esta comunidade permitiu-lhe manter excelentes redes sociais por todo mundo, redes essas propícias aos negócios (ANTUNES,2009, p. 146).

Moravam no Nordeste vários estrangeiros, flamengos, ingleses, franceses, às vezes consorciados com mulheres lusas, indígenas, ou afro-brasileiras, ou com mercadores donos de rentáveis negócios. Em suas pesquisas sobre os cristãos-novos na Bahia, Anita Novinsky assegura que os sefarditas se integraram muito bem à sociedade colonial, ao participar dos empreendimentos econômicos e de cargos públicos, como homens de bem, inclusive na governança, juntamente com as autoridades metropolitanas. Quem provocou o conflito foi a Inquisição (NOVINSKY, 2009).

\section{A TIRANIA DO INIMIGO COMUM}

Entre 1580 e 1640, ocorreu a união das coroas ibéricas Portugal e Espanha. Felipe II da Espanha assumiu o governo dos dois países ibéricos e como fervoroso católico, intensificou as perseguições aos protestantes e aos judaizantes. As primeiras Visitações da Inquisição ao Brasil aconteceram no período filipino: a Primeira Visitação do Santo Ofício ocorreu entre 1591 a 1593; a Segunda Visitação deu-se entre 1618 e 1620. Nas Terras Brasilis não houve um Tribunal da Inquisição, considerou-se como um empreendimento oneroso, mas sua ação repercutiu no território, com as referidas Visitações do Santo Oficio.

A presença de cristãos-novos e de protestantes no comércio colonial justificava a vigilância inquisitorial. A visitação ocorria em cidades, naus e livrarias. Tratava-se de "uma inspeção periódica, que, por determinação do Conselho Geral do Santo Ofício, realizava um 
delegado seu para inquirir do estado das consciências em relação à pureza da fé e dos costumes” (SIQUEIRA, 1978, p. 183). O Brasil estava vinculado à Inquisição de Lisboa. Na ausência dos funcionários inquisitoriais um clérigo, poderia ser investido como agente do Tribunal. “Até o estabelecimento da rede de oficiais na Colônia, era o prelado o agente do Tribunal inquisitorial na América Portuguesa" (SOUZA, 2014, p. 97).

A intolerância era de parte a parte: para os protestantes, a Igreja Católica era a adversária a ser combatida e denunciada. João Cointas, remanescente da França Antártica, inicialmente foi considerado suspeito de seguir o Catolicismo. Segundo Jean D’Lery, o francês foi aceito com dificuldade na comunidade: "Não tínhamos em boa conta um tal senhor João Cointas, que viera conosco... foi ele convidado a fazer confissão pública de sua fé antes de comungar, o que fez, abjurando perante todos o papismo. " (LÉRY, 1980, p. 90). João Cointas, Senhor de Bolés, foi processado em 1560 pelo Bispo D. Pero Leitão, na Bahia, acusado de heresia pelo jesuíta Luiz de Gram. No Tribunal de Lisboa foi preso nos Estaus e posteriormente, queimado em Goa.

Entre os reformados, os católicos recebiam a alcunha de papistas, entre os católicos estes eram designados como hereges. Para os judeus, os católicos representavam a tirania e a idolatria, na perspectiva da Igreja Católica os seguidores de Moisés eram deicidas. Quanto aos cristãos-novos, estavam sempre sob suspeitas de judaizar. O acolhimento a cristãos-novos era também uma forma de contestar o Catolicismo. Em 1676, o francês Charles Dellon, condenado pela Inquisição de Goa, ficou preso alguns meses na Bahia aguardando o navio que o levaria a Lisboa. Seu relato Relation de Inquisition de Goa foi publicado a primeira vez em 1687 na calvinista cidade de Leiden e divulgado em alemão, inglês e neerlandês (DELLON, 1997).

A proximidade dos cristãos-novos com os protestantes tornava-se um agravante perante a Inquisição. Na Primeira Visitação o cristão-novo Salvador da Maia, morador em Ilhéus, parente da família Lopes, foi processado e acusado de ter uma sinagoga. O denunciado morou em Flandres, mas confessou não ter contatos com os luteranos. No imaginário colonial, os líderes reformados e suas "heresias" eram marcantes. Eis o retábulo encontrado na "Snoga" de João Brás, um cristão velho, denunciante de Salvador da Maia:

Estavam os sete sacramentos da Igreja precedidos do lado da figura de Cristo e mais
os apóstolos ...figuras dos sacramentos, a figura da santíssima trindade e corte celestial
e por baixo estava um mar em que estavam afogados muitos hereges, Calvino, Lutero
(Inquisição de Lisboa, Processo 2320).

Não sabemos até que ponto o retábulo era um nicho para adoração, ou uma ironia, que representava as três grandes confissões religiosas em disputa na Europa e na América 
Portuguesa. O certo é que no retábulo do cristão velho apareciam os principais símbolos do Cristianismo, as Escrituras Sagradas, o livro que presidia representações, doutrinas e práticas dos cristãos, a Igreja Católica como uma árvore e as figuras dos heréticos Lutero e Calvino afogados no mar, castigados com a morte, pena máxima da Inquisição. Fazer cerimônias judaicas frequentar sinagoga, ou participar de cultos luteranos era pecado. Um bom católico não deveria participar de cerimônias religiosas heréticas.

Na visitação de 1591, a cristã-velha, Leonor Carvalha, foi à mesa inquisitorial pedir perdão, pois quando jovem, em Arzila (Marrocos) visitou uma sinagoga por curiosidade:

\footnotetext{
Entrou numa snoga de judeus, na qual não havia cruz, nem imagem de Deus, nem de santos, senão uma Cantareira com um frontal de pano da India pintado, na qual Cantareira estavam uns rolos, que diziam ser pergaminhos, enfronhados em uns sacos de linho...estavam alguns judeus assentados num banco falando alto, entoando entoada bé, bé. (VAINFAS, 2005, p. 126).
}

Inquirida pelo Visitador Furtado de Mendonça se alguém lhe disse que a lei de Moisés era boa, Leonor Carvalha tratou logo de desculpar-se dizendo que pessoa alguma lhe ensinara e também silenciou sobre o fato ocorrido em sua juventude: "ela tomou grande aborrecimento das ditas cerimônias dos judeus e lhe pesou de as ter visto. Pede perdão no tempo da Graça" (VAINFAS, 2005, p. 127, 128). Acusar-se e pedir perdão pelo pecado cometido era a garantia de receber a misericórdia divina, naquele momento personificada na figura do visitador.

Na Visitação de 1591, a cristã-nova Ana Rodrigues foi acusada de manter uma sinagoga no Engenho Matoim, no Recôncavo da Bahia. Senhora octogenária fazia parte de uma poderosa família cristã-nova, a família Antunes. Foi presa e enviada para o cárcere em Lisboa, onde faleceu e posteriormente queimada na fogueira em efígie. Na porta da capela do Engenho Matoim foi exposto um quadro retratando-a nas labaredas entre seres demoníacos, isto é, queimada no inferno (DENUNCIAÇÕES DA BAHIA, 1925, p. 337, 338).

As heresias luteranas rondavam a Terra Brasilis. Na Primeira Visitação na Bahia, confitentes se apresentaram acusando-se de intercursos com luteranos, na verdade calvinistas, a exemplo do francês Pero da Vila Nova que se apresentou no Tempo da Graça, relatando que era filho de católicos, mas frequentou escolas luteranas na França Antártica, veio em 1557 para o Brasil "com monsenhor De la Xapella, monsenhor De Bolex e muita gente francesa, a maior parte eram luteranos" (VAINFAS, 1997, p. 192). Durante a invasão francesa ao Rio de Janeiro se refugiou entre os cristãos. Pedia perdão, pois o Tempo da Graça era uma ocasião para o 
exame de consciência, dos faltosos confessarem as culpas, se livrarem das penas, que variavam desde levar velas para a Sé, até o sequestro de bens e a morte.

Alguns cristãos velhos, que tiveram contatos com reformados, também se sentiam culpados e buscavam o perdão: o cristão velho Baltasar Barbosa, morador de Sergipe, apresentou-se no Tempo da Graça relatando uma conversa, que teve há mais de vinte anos, com luteranos, de fato calvinistas, sobre o poder do Papa para perdoar pecados, inclusive as próprias blasfêmias deles. O confitente declarou: "que nunca teve, nem tem tal dúvida, e que bem creu e sabia que o papa tem todos os poderes de Deus para perdoar aos luteranos, convertendo-se eles à fé católica" (VAINFAS, 1997, p. 239). O Visitador Heitor Furtado de Mendonça admoestou o polemista e recomendou o seu retorno à mesa inquisitorial dois meses após a confissão, o que denota precaução.

Na Primeira Visitação, em Pernambuco, o flamengo Antonio Vilhete, encaixador dos açucares, foi denunciado por ter discutido com o cristão velho Pero Luis que não havia purgatório, segundo o holandês: “o purgatório era por ay ao pee de hum pao ou onde Deos queria ...dittas palavras negar o purgatório do outro mundo, lhe parecerão mal por ele ser estrangeiro" (CONFISSÕES DE PERNAMBUCO,1984, p. 233). A doutrina do purgatório da Igreja Católica foi rechaçada por Lutero, como um pretexto papal para angariar dinheiro. Para o Catolicismo, a não aceitação do estado intermediário da alma, era erro dos reformados.

Discórdias e interesses materiais também suscitaram divergências entre cristãos velhos e protestantes. Na Primeira Visitação em Pernambuco, o flamengo André Pedro com quem "tinha fiados" e o inglês Alberto Carlos, que vivia cobrando dívidas, foram denunciados por Agostinho de Holanda, meio alemão e cristão velho, de terem

\footnotetext{
Conversas luteranas, ambos disseram a heresia melhor lei é da nossa terra de se confessarem ao pé de um altar a Deos somente, do que era a nossa de nos confessarmos a confessores, porque os confessores vão descobrir os pecados que se lhe confessam (CONFISSÕES DE PERNAMBUCO,1984, p. 253).
}

Na Bahia, em 1604, o holandês Alberto Jacobo, flamengo cristão velho, marinheiro, natural de Arlem foi preso e enviado aos Estaus, em Lisboa, sob acusação de luteranismo, conforme parecer do Jesuíta Fernão Cardim. O réu, no processo que durou de 1604 a 1606, era menor de 21 anos teve curador, um tradutor, o Jesuíta Diogo Nevis, pois dizia não saber falar português. Alcunhado de Broque trabalhava no engenho do cristão-novo Fernão Ribeiro, em Salvador. Inquirido sobre as acusações heréticas que pesavam sobre ele: respondeu que era 
costume de sua terra e que não rezava as orações, nem se confessava porque se sentia incomodado, por não saber as orações em português.

Em 1606, Alberto Jacobo voltou à mesa inquisitorial. $\mathrm{O}$ inquisidor perguntou-lhe se frequentou igrejas luteranas e se foi ensinado nos erros da seita. $\mathrm{O}$ prisioneiro respondeu que trabalhou em navios mercantes de Holanda, onde tinha cristãos e luteranos que o chamavam de Papista, pois era católico, não aceitava a dita heresia e que havia tão bons católicos na sua terra como os de cá, bem como, um só Deus e o Cristo Redentor que padeceu para salvar a todos. Reafirmou ser cristão e que o Papa e os santos contribuem para a salvação de sua alma. Após 4 anos de prisão foi solto com o juramento de fidelidade a Igreja Católica e pagamento das custas do processo. (ARQUIVO TORRE DO TOMBO, PROCESSO ALBERTO JACOBO 03618).

Na segunda Visitação (1618-1620), D. Marcos Teixeira foi o visitador. Vários cristãosnovos foram denunciados e outros se confessaram no Tempo da Graça. Destacamos a família Lopes, que migrou no início de 1557 para a Bahia, na mesma nau "em que veio para o Brasil o então Governador-Geral Mem de Sá”, conforme as pesquisas de (SILVA, 2013, p. 38). Uma família que se relacionou com cristãos-novos, com velhos cristãos, mercadores flamengos calvinistas e a estrutura política, fincando raízes e amealhando riquezas. Preservaram práticas judaicas e membros da família foram denunciados pela Inquisição (ASSIS, 2004).

O cristão-novo Diogo Lopes Franco, de 26 anos de idade, mercador e morador do Matoim, da nação, comparecera diante do Visitador D. Marcos Teixeira, em 1618, em Salvador, no Tempo da Graça, se acusando que colocou a mão nas imagens dos apóstolos que saíram na Ceia da Quinta Feira de Endoenças e fazia comparações, "dissera q se parecia cô o "Meirinho do Mar...disso pedia perdão e estava arrependido e obediente para a penitência que se lhe desse" (SIQUEIRA, 2011, p. 124, 125). Inquirido pelo Visitador, Lopes Franco confessou que seu pai Luis Dias morrera preso no Santo Oficio e queimado em estátua. Após admoestação para preservar a doutrina e veneração as imagens foi intimado a retornar à mesa inquisitorial.

Em setembro de 1618, em Salvador, no Tempo da Graça, apresentou-se ao Visitador Marcos Teixeira, João D’ Araújo, holandês, vinte e seis anos, seguia a seita calvinista, era chamado de Abraham Cabalhão e sua genitora morava na Inglaterra. Cabalhão era proveniente de Leiden, cidade calvinista, com um intenso comércio e indústria de algodão, além dos produtos coloniais, tabaco, açúcar, madeira e prata (ISRAEL, 1998). Cabalhão/ D’Araújo trabalhava com o cristão-novo Diogo Lopes Franco, no engenho Matoim, já visado pela Inquisição na Primeira Visitação. 
Abraham Cabalhão, ao chegar à Bahia, trocou de identidade e passou a se denominar, João D'Araújo, e se passava como inglês, certamente sabedor que os ingleses tinham regalias nos domínios lusitanos. Trocar o nome também foi uma prática recorrente entre os judeus e cristãos-novos. Na mesa inquisitorial, o holandês afirmou que pretendia deixar seus heréticos erros, pedia perdão "queria ser instruído em nossa santa fé Católica porque sua vontade e tê-la e crê por ela morrer" (SIQUEIRA, 2011, p. 182). Abjurava do calvinismo e queria ser instruído na verdadeira fé. Inquirido respondeu que os mercadores Afonso Dias Henrique, cristão-novo e Antonio Dias de Moraes de Antuérpia sabiam de sua origem calvinista. Perdoado da heresia, o Visitador lhe ordenou que continuasse a ser doutrinado pelo Jesuíta Hierônimo Peixoto.

A documentação da Inquisição, o inimigo comum dos judeus e dos protestantes, também comprova uma afinidade eletiva, que se tornou uma prática recorrente na América Portuguesa, a saber, a leitura dos textos sagrados da tradição judaico-cristã tanto por cristãos-novos quanto por protestantes. Era um compartilhamento da literatura sagrada lida por judeus e calvinistas no período colonial. A Torá ou Toura, conforme grafado na documentação, são os cinco primeiros livros da Bíblia Hebraica, os primeiros livros, também aceito pelo cânone cristão, que constituem o Velho Testamento, juntamente com o livro de Salmos, em sua maioria atribuídos a Davi (KIBUUKA, 2019).

Antes da Primeira Visitação já circulavam livros proibidos nas terras brasílicas. O mercador italiano Rafael Olive, morador de Ilhéus, em 1574 foi preso, a mando do Padre Gaspar Mendes por ter livros defesos. Segundo Janete de Macedo “era a maior biblioteca particular no Brasil colonial, no século XVI. Estava em Ilhéus, no engenho São João. ” (MACEDO, 2009, p. 21). Culto, demonstrando menosprezo com as "coisas" da Igreja, Olive foi visto pelos vizinhos como "Lutero", isto é seguidor das doutrinas protestantes.

Na visitação de 1591, a cristã-nova judaizante, Maria Lopes "foi acusada de ter uma imagem dentro d uma almofada [...] e ter a Bíblia em linguagem em que lia por ela sendo esta fama pública " (SILVA, 2013, p. 101). Ocorriam visitações aos navios de estrangeiros e às livrarias, impedindo a circulação de livros que ameaçavam a ortodoxia católica. "O controle das leituras não só dos trabalhos publicados, como o dos que deviam ser impressos era peça de enorme mecanismo de isolamento da heresia ou de caminhos que disfarçadamente ela pudesse conduzir " (SIQUEIRA, 2013, p. 673-674).

Na Primeira Visitação, em Pernambuco, o mercador inglês Thomaz Bebitão acusado de praticar a sua religião, isto é, o anglicanismo e sua mulher, a cristã-nova Maria Peralta foi denunciada por ensinar aos filhos os Salmos, que tinha uma "Bíblia em linguagem" e havia REVISTARELEGENSTHRÉSKEIA - 2020 - UFPR 
esbofeteado uma imagem. A senhora Peralta foi denunciada por um cristão-novo, o poeta e professor, Bento Teixeira, que ensinava os seus filhos a ler e havia morado na Bahia. Ao conversar com outros cristãos-novos recomendou a leitura do "tratado que fez o bispo Hieronimo de Osorio contra os judeus e nele acharia os testemunhos falsos que eles alevantavam contra Cristo nosso Redemtor" (CONFISSÕES DE PERNAMBUCO, 1984 p. 161, 162). Um círculo de leitores se formou na Terra Brasilis disputando narrativas religiosas e a Inquisição estava atenta.

O cristão-novo, Bento Teixeira, morador em Pernambuco, provou do mesmo veneno, ao ser acusado de judaizar pela própria mulher, após assassiná-la, foi conduzido preso para Lisboa, onde publicou o poema Prosopopeia, um elogio as elites dominantes de Pernambuco. Julgado pela Inquisição de Lisboa, constava em suas acusações: "possuía livros, alguns proibidos, que confessou ler. Fez a pedido de amigos e parentes, a tradução da Bíblia, o que na época era considerado crime" (RIBEIRO, 2006, p. 204).

Em 1619, o Visitador Marcos Teixeira convocou Cabalhão/ D’Araújo para ratificar o seu depoimento. O holandês relatou que encontrou dois livros no escritório de um cristão-novo: o Saltério de David e os Salmos. O regimento de 1613 previa, como para os editais da fé, a leitura anual dos editais dos livros proibidos. Os Salmos de David e o Saltério, um hinário dos reformados neerlandeses, faziam parte dos livros devocionais protestantes, com traduções em português e espanhol, circularam no território brasileiro. Os mesmos mercadores que levavam e traziam mercancias dos Países Baixos traziam os livros, proibidos pela Igreja Católica.

Instruído na leitura devocional das Escrituras, o ex- calvinista, não resistiu e "um dia lendo por um deles entrara Luis Alvarez da Nação morador em casa de Manoel Roiz Sanches também da Nação e lhe dissera q o livro era defeso, e o havia de levar para queimar e com efeito o levou" (SIQUEIRA, 2011, p. 185). Semelhante a certos cristãos-novos, Abraham Cabalhão continuou secretamente calvinista e publicamente aderiu ao Catolicismo. No Brasil holandês, “o encontraremos em Recife como mercador e escabino, a serviço de Mauricio de Nassau e da Igreja Reformada" (SILVA, 2017, p. 112).

Na Visitação de 1618, apresentou-se no Tempo da Graça, Luiz Alvarez, caixeiro da nação, natural do Porto, que "em Anvers (Antuérpia) aprendera a língua flamenga, francês e livro de caixa, onde esteve dois anos". O Visitador interrogou: "por estas terras donde andou lhe ensinarão alguns erros contra a santa Fé e principalmente contra o Sacramento da Missa disse não" (SIQUEIRA, 2011, p. 75). Após juramento de seguir a reta doutrina católica, Alvarez foi dispensado. No depoimento de Cabalhão, o caixeiro foi citado como alguém que sabia o REVISTARELEGENS THRÉSKEIA - 2020 - UFPR 
significado de livro defeso. Livros defesos era uma forma de garantir a ortodoxia católica. "Desde o século XVI, que a publicação de listas de livros proibidos condicionou o acesso a obras de autores considerados divulgadores de idéias contra a fé " (BRAGA, 2002, p. 257). A literatura judaica ou protestante era proibida de circular.

Na segunda Visitação do Santo Oficio (1618), Manoel Homem de Carvalho, preso na Bahia, confessou a D. Marcos Teixeira, que frequentou a sinagoga em Amsterdam, que "leu a Bíblia impressa traduzida em castelhano e solicitava perdão e misericórdia pelos erros cometidos contra a Igreja Católica" (SIQUEIRA, 2011, p. 280).O Padre Balthazar Ribeiro, da nação judia, morador de Salvador, foi "denunciado por ter lido uma Bíblia em linguagem castelhana, saída de Flandres, entre 4 a 5 mil volumes, bem como Diogo Lopes Franco, Diniz Bravo, Paschoal Bravo, Diogo Albuquerque, dentre outros, denunciados pelo mesmo crime" (LIVRO DAS DENUNCIAÇÕES DA BAHIA, 1925 p. 116). Segundo Araújo, (1999), as proibições eclesiásticas, especialmente do Concilio de Trento, e o Index Prohibitorum de 1564, inibiram a prática da leitura e no século XVI e XVII quase não existiam livros na Bahia, eram poucos exemplares. Os proprietários de livros, especialmente da Bíblia ou de Salmos, seriam raros e suspeitos de desobediência aos princípios católicos.

Muitos livros dos sefarditas foram impressos em Amsterdam, incluindo os textos sagrados, publicados em português ou espanhol. "Entre 1580 e 1820 mais de 700 livros em espanhol ou português, panfletos e brochuras foram impressos na Holanda. A República permitia grande liberdade de imprensa " (BOER, 1988, p. 98). A família Soeiro, do Rabino Menasseh Ben Israel possuía uma tipografia em Amsterdam, na qual foram impressos muitos dos livros proibidos pela Inquisição Portuguesa e a Espanhola.

Em Portugal nos séculos XVI e XVII havia várias colônias de estrangeiros protestantes, 248 foram processados pela Inquisição Portuguesa, acusados de luteranismo ou calvinismo. Em número de 66 neerlandeses foram processados nos Tribunais da Inquisição de Lisboa, Évora e Coimbra (BRAGA, 2002). Os cristãos-novos representavam o maior número de prisioneiros no Brasil: 1.076 presos entre homens e mulheres. Nove prisioneiros acusados de luteranismo, dentre outros que abjuraram e se tornaram católicos (NOVINSKY, 2009).

Os cristãos-novos, que habitavam o Brasil, não estavam apenas consorciados com os flamengos calvinistas no comércio colonial. Desenvolveram estratégias de enfrentamento semelhantes contra o inimigo comum, que era a Igreja Católica e o Tribunal do Santo Oficio. $\mathrm{Na}$ Primeira Visitação ao Brasil foram contabilizadas 40 confissões com referências ao luteranismo, geralmente vinculadas a mercadores e marinheiros que contataram com navios de REVISTARELEGENSTHRÉSKEIA - 2020 - UFPR 
ingleses, holandeses e franceses. Na Segunda Visitação, há mais de uma dezena de confissões que reportam os Países Baixos, Amsterdam e La Rochelle, como terra de hereges.

O supliciamento do jovem judeu Izaque de Castro, preso na Bahia e morto em Lisboa em 1648, teve uma forte repercussão negativa na Sinagoga Portuguesa em Amsterdam, que lhe prestou homenagens e exéquias solenes de mártir, bem como nas instâncias políticas, pois “ não se dispondo a consentir em tal abjuração fora por isto queimado vivo" (LIPINER,1992, p.257). Os Estados Gerais exigiam providências ao Rei de Portugal, inclusive para os três jovens judeus, aprisionados no Brasil e que ainda estavam presos em Lisboa.

Os protestantes não tiveram um tribunal inquisitorial, porém desenvolveram práticas inquisitoriais contra religiões e doutrinas divergentes. Os faltosos, julgados pelo Consistório de Genebra, eram admoestados ao arrependimento, porém se persistissem nos erros eram condenados severamente. "Os heréticos, os contendores, os questionadores eram excomungados e afastados de todos os sacramentos, mas também de toda assembléia" (GARRISON, 1991, p.115). Com a união dos poderes civis e religiosos, a liderança de Calvino se agigantou e o Consistório ganhou peso, como tribunal eclesiástico, com penas de morte.

A trajetória de Miguel de Serveto é um exemplo da intolerância calvinista: o médico espanhol conseguiu fugir da prisão inquisitorial de Lyon e dirigiu-se à Genebra em busca de proteção. Calvino não o apoiou e o dissidente espanhol caiu nas garras do Consistório. Um pensador rejeitado, ao mesmo tempo, pelos católicos e pelos reformados. Preso em Genebra, Serveto foi condenado por heresia em 1553, juntamente com os livros que havia escrito foi queimado na fogueira do Consistório. "A tirania espiritual que Calvino denunciara na Igreja Católica, agora era posta em prática pelos próprios protestantes com o seu aval teológico e moral" (SILVA, 2019, p.135).

\section{O CONSÓRCIO COMERCIAL E A LIBERDADE DE CONSCIÊNCIA}

As relações comerciais entre lusitanos e flamengos remontam ao século XIII com a feitoria Portuguesa de Antuérpia e o comércio do sal. Os capitais para fabricar o açúcar, o refino e distribuição na Europa eram feitos pelos flamengos, especialmente das Províncias Unidas do Norte, os calvinistas que enfrentaram a Espanha e tornaram-se independentes constituindo-se como República e proibidos de fazer o rentável comércio com a Terra Brasilis.

Já ao final do século XVI, os holandeses exploravam a América do Sul. Em 1580, o neerlandês Abraham Cabeliau, um ascendente de Abraham Cabalhão, que morava na Bahia, 
em 1618, membro de uma família de comerciantes calvinistas, explorou o Caribe: "escreveu um relato de viagem prefaciado pelo Príncipe de Nassau, um roteiro para a Companhia das Índias Orientais, organizada em 1602, pelas Províncias Calvinistas do Norte e em 1621 a Companhia das Índias Ocidentais. (SILVA, 2017, p. 93).

Capitalistas judeus, dos Países Baixos, também eram acionistas em ambas companhias de comércio. Conforme Schama, "os empresários de Leiden se aproximavam muito do tipo ideal de Weber" (SCHAMA, 1992, p. 338). As autoridades estavam atentas aos interesses que os produtos tropicais, especialmente o açúcar, despertavam entre os holandeses. Em dezembro de 1603, o Governador Diogo Botelho recebeu uma missiva de Lisboa alertando: "nas ilhas de Holanda e Zelândia se ficam acabando de aprestar e pôr em ordem até 30 navios com muita gente e munições para fazer alguma empresa e partir com brevidade de ir acometer-se esse estado do Brasil pela Bahia ou R. de Janeiro " (Livro de Cartas de S. Majestade, 1692, p. 32).

Com a independência dos Países Baixos, os flamengos foram impedidos de continuar os lucrativos negócios com a América Portuguesa. “O ataque maciço dos holandeses ao Império Colonial Português foi ostensivamente motivado pela união das Coroas portuguesa e espanhola na pessoa de Filipe II da Espanha, contra cujo Governo, nos Países Baixos, se tinha revoltado os Holandeses em 1568. " (BOXER, 1981, p. 118).O crescente número de cristãos novos e as suas afinidades com as Províncias do Norte rebeladas contra a Espanha era uma ameaça à Monarquia e à Igreja Católica, que lhe dava sustentação ideológica.

Em 1604, ocorreu o primeiro ataque de holandeses à Baía de Todos os Santos, com apresamento de mercadorias, prontamente reprimido pelas autoridades (PÉREZ, 2013, p. 141). Não ganhou repercussão na historiografia, porém é um sinal que os flamengos já conheciam a cidade e como seria a resistência a um futuro ataque à Terra do Açúcar.

A quantidade de engenhos deu ao Brasil o epiteto de Terra do Açúcar, um dos produtos mais importantes da pauta comercial do período. Um manuscrito anônimo do século XVII, existente na Universidade de Leiden, descreveu com tintas superlativas a capitania da Bahia: "muy excelente [...]. Metropoli de toda la província, cabeça de todo o Estado." (MARQUES, 2011, p. 123). O jurista Hugo Grotius escreveu um tratado defendendo a liberdade dos mares, De Mare Liberum, em 1609, contestando o monopólio ibérico. Ávidos de lucros os neerlandeses fundaram colônias e feitorias nos domínios ibéricos.

A Bahia era o foco da cobiça: a Companhia das Índias Ocidentais entregou o comando a Jacob Willekens de uma esquadra, que aportou na Baía de Todos os Santos em maio de 1624. 
Os invasores não encontraram resistência, o Governador Mendonça Furtado foi aprisionado e o neerlandês J. Van Dorth tomou posse da cidade, confiscava o açúcar e castigava os padres:

Caíram, ainda em nosso poder alguns navios, um de Lisboa, de cerca de 50 a 60 lastros, carregado de óleo, pão e mercadorias, 2 do Rio de Janeiro, carregados de açúcar, nos quais se achavam 9 jesuítas, com o respectivo provincial, 2 franciscanos e 4 beneditinos.(RELATÓRIO apud VARNAGHEN, 1872, p. 335).

Os neerlandeses receberam o reforço de 600 angolanos e alguns cristãos-novos que habitavam Salvador. O Bispo D. Marcos Teixeira, organizou a defesa em nome do Rei e da fé cristã, contra os heréticos invasores: pelejarem até a morte por sua fé e Rei. A ocupação da cidade soteropolitana durou um ano, os holandeses, seguindo uma prática usual após a Reforma, despiram os templos de Salvador dos símbolos católicos e passaram a realizar cultos calvinistas. Segundo o relato da Jornada Del Brasil, escrita pelo soldado espanhol Juan de Guzman, que participara da guerra, os "holandeses faziam suas orações luteranas na Igreja de São Benedito" (GUZMAN, MIRAFLORES y SALVA, 1870, p. 156). Era o espaço do Mosteiro de São Bento.

Havia na armada invasora sete pastores: o Reverendo Johannes Nender faleceu na Bahia; Jacobus Dapper, Valentinus Artopaeus, J. C. Pick, J. Michaelise, H. Wisman e o Reverendo Enoch Sterthenius. (SCHALKWIJK, 1989, p. 100). Em 1623, nas atividades do Conselho Eclesiástico da Igreja Reformada, em Midelburgo, constavam os esforços para "enviar o predicante Enoch Sterthenius para o Brasil, acompanhando os comerciantes da Companhia das Índias Ocidentais" (SILVA, 2017, p. 93). O Pastor Sterthenius fez o sermão de ações de graças pela ocupação da Bahia, agradecendo a Deus a nova Conquista: "A todos os feitos somente a Deus Nosso Senhor cabe a honra" (VARNHAGEN, 1872, p. 335).

O relato da conquista de Salvador demonstra como os objetivos mercantis e religiosos se imiscuíam nos empreendimentos neerlandeses da Companhia das Índias Ocidentais:

\footnotetext{
Entraram na cidade sem encontrar resistência. Encontraram, em algumas casas, a mesa ainda posta [...] de tão apavorada a população fugira durante a noite. Isto é um sinal da ajuda miraculosa do Senhor que, pelo seu braço forte, afastou de nós os nossos inimigos e os seus bens nos deu como despojo. (TEENSMA, 2013, p. 87).
}

Como aos hebreus do Antigo Testamento, o Senhor dos Exércitos havia dado a vitória aos calvinistas contra os papistas. Laet registrou: "ações ilustres, que os Estados das Províncias Unidas têm praticado em nossos dias [...] manter a verdadeira Religião e defender a nossa liberdade" (LAET, 1912, p. 37). A verdadeira religião era o Calvinismo e a liberdade era independência da Espanha.

REVISTARELEGENSTHRÉSKEIA - 2020 - UFPR 
Os ibéricos venceram a guerra, a Igreja Católica reagiu contra os hereges. Conforme os beneditinos: "Invadiram os Olandeses esta terra, era uma infernal mistura de Luteranos e Calvinistas, e prim. objecto de suas dannadas intenções foi o total estrago dos templos sagrados, aos quaes ao depois de roubados e saqueados os arrasarão." (LOSE, 2009. p.74-75). Segundo o cronista, as armas ibéricas triunfaram contra "os mortaes inimigos da fé catholica" (LOSE, 2009, p. 75). Opinou o autor da Jornada dos Vassalos: “a dura contumácia de Holandeses hereges e rebeldes a Deus na Fé, e à sua Majestade na sujeição são hoje os maiores inimigos da Igreja Católica e da paz política das Coroas de Espanha” (GALINDO,2010, p. 44).

A polêmica sobre o apoio de cristãos-novos aos invasores é um falso problema. Novinsky defende que "cristãos novos moradores da Bahia participaram da defesa do território brasileiro durante todo o tempo em que esteve ameaçado pelos holandeses" (NOVINSKY,1972, p. 129). A questão foi de ordem militar: era mal protegida a cidade de Salvador e o seu Recôncavo. O Bispo D. Marcos Teixeira teve que formar tropas populares, especialmente com os indígenas aldeados, habilidosos na guerra brasílica. O governo filipino em 1625, pós expulsão dos neerlandeses criou "uma guarnição militar na Bahia composta por mil soldados. O primeiro exército efetivo do Brasil " (MAGALHÃES, 2016, p. 92).

O Rabino Israel, de Amsterdam, fez o elogio público à Republica Holandesa e ao Príncipe: "Nós portugueses, achamos refúgio no seu seio, testemunhamos a sua justiça. Agora estavam vivos, agora estavam salvos e desfrutando de plena liberdade. Isto é o grande sinal de sua virtude, um grande sinal de sua coragem " (NADLER, 1992 p. 109). Continuou o discurso de Israel: "Se Moisés tirou os israelitas do Egito, a terra de muitos deuses, também a Casa de Orange libertou as Províncias Unidas da idolatria dos senhores da Espanha Católica" (NADLER, 1992, p. 110). Conforme o Rabino Israel, um pacto de lealdade e reconhecimento unia sefarditas e holandeses, ao tempo em que se auto expatriavam de suas origens ibéricas:

\footnotetext{
Somos protegidos por Deus Poderoso de todos os perigos...agradecidos a Vossa Alteza e aos ilustres Estados da Holanda por nossa liberdade. Já não consideramos Castela e Portugal nossa pátria, mas a Holanda. Não pensamos nos reis espanhóis ou portugueses como nossos senhores, mas nos Estados de Holanda. (NADLER, 1992, p. 110).
}

Se a Holanda era agora a pátria dos judeus, nada mais natural do que se aliar aos holandeses contra o inimigo comum. $\mathrm{Na}$ assinatura do armistício entre holandeses e ibéricos (1625) em Salvador, o Reverendo Sterthenius opinou que "judeus gente que não era de muita confiança e deveria juntar todos os reinos cristãos e fazer guerra aos turcos" (MIRAFLORES: SALVA, 1870, p. 177). Talvez, fosse uma forma de livrar os aliados do castigo, a exemplo dos REVISTARELEGENSTHRÉSKEIA - 2020 - UFPR 
cristãos-novos Dinis Bravo, Pascoal Bravo, Manoel Rodrigues Sanches, Duarte Alvares Ribeiro, comerciantes de açúcar denunciados de terem ajudado os invasores holandeses. Os indígenas e africanos que lutaram com os neerlandeses foram mortos (TAVARES, 2001).

Os flamengos não desistiram de conquistar a Terra do Açúcar. Em 1630, uma armada holandesa aportou em Olinda e ocupou a cidade. Conforme o relato dos neerlandeses: "tomaram o mosteiro dos Jesuítas, que era o ponto mais forte e Graças à ajuda de Deus, tomou posse da cidade" (TEENSMA, 2013 p. 93). Acompanhou a armada invasora os pastores Wilhelmus Pistoris, Lambertus Latonius, Jacobus Martini e J. Baers, conselheiro do comandante Waerdenburch. Em Olinda Conquistada, o calvinista a serviço da Companhia das Índias Ocidentais, registrou a conquista de Pernambuco: "ilustre feito [...] uma jubilosa nova para os amigos da Pátria que veneram a Deus, o bem-estar da República e desejava a propagação da santa palavra divina e a salvação das almas de muita gente" (BAERS, 2004, p. 15).

Comerciantes holandeses residentes em Pernambuco foram contratados pelos invasores da Companhia das Índias Ocidentais e passaram a colaborar com os mesmos. (MELLO, 1947). Eis o relato do primeiro culto calvinista: "fez as preces e uma prédica sobre o texto do Êxodo capítulo XVII, versos 8-14 e depois o salmo XIV, terminando com uma pia e fervorosa oração. " (BAERS, 2004, p. 14). O texto bíblico lido era emblemático: narra a conquista da terra dos amalequitas pelos hebreus, rumo à Terra Prometida. "O Brasil e as suas riquezas era a terra prometida aos filhos de Deus calvinistas e os inimigos eram os infiéis ibéricos seguidores do Papa " (SILVA, 2017, p.100). A narrativa da trajetória dos hebreus na Antiguidade era usada tanto pelos calvinistas quanto pelos judeus. O Nordeste traria lucros à Holanda, o Reverendo se reportou ao "iate De Brack, o qual foi carregado com açúcar para que eles saboreiem os primeiros frutos da terra, que mercê de Deus conquistamos" (BAERS, 2004, p. 46).

A Igreja Reformada funcionou no Nordeste, com classes, conselho e presbitério. Os cultos eram destinados aos protestantes, porém, desde o início da ocupação divulgavam o calvinismo. Segundo o Reverendo, "muitos pretos e pretas que a seu modo atendiam, quietos e devotos ao ofício divino eram também batizados " (BAERS, 2004, p. 47). Os indígenas foram evangelizados e uma congregação foi organizada com predicantes indígenas, que haviam estudado na Universidade de Leiden. Conforme Schalkwijk, “já no ano de 1598, o Consistório de Amsterdam assumira a liderança missionária nas Províncias Unidas " (SCHALKWIJK, 1989, p. 219). No governo Nassoviano (1637-1644), as missões calvinistas se consolidaram e construíram os primeiros templos protestantes na América Portuguesa. 
Circularam livros devocionais calvinistas e exemplares da Bíblia chegavam a Recife livremente, com outras mercadorias, vindas da Holanda. Quando do casamento do holandês Johan Wynants, de Haarlem, com a portuguesa Catarina, em 1635, a mãe dele remeteu ao casal "uma Bíblia, seis barriletes de biscoitos,296 libras de queijo,6 presuntos,7 pedaços de carne defumada.1/2 barril de manteiga, peças de tecidos variados." (MELLO, 1979, p. 41).

No período Holandês considera-se, que houve tolerância religiosa pela primeira vez no Brasil. Publicamente, a primeira sinagoga da América fundada em Recife, em decorrência da presença de capitalistas judeus na Companhia das Índias Ocidentais e do espírito renascentista do Conde Nassau. A convivência era mais ou menos pacífica. Frei Callado registrou que "Nassau permitiu às Igrejas os seus ofícios e duas sinagogas de judeus. Era um homem de sangue real inclinado ao bem. " (CALLADO, 1985, p. 50). Como um habilidoso político, afeito à retórica do Renascimento, Nassau recebia religiosos católicos, ao mesmo tempo em que se acercava de judeus ilustres.

Segundo G. Barléu, biografo de Nassau, os cristãos-novos, libertos da tirania espanhola, no Brasil holandês, eram livres para praticarem suas crenças.

\footnotetext{
Grande parte dos habitantes judeus daqui vieram da República Holandesa. Alguns deles, originalmente portugueses, simularam a conversão a fé cristã sob o domínio do rei espanhol. Agora, sob o reino de regentes mais tolerantes, livres do receio da persecução, associam-se abertamente aos judeus. (BARLÉU, 2018, p. 196).
}

O clero da Igreja Reformada em Pernambuco contestava a liberdade concedida aos judeus, os quais “desonravam a verdadeira doutrina de Cristo". Na Classe de 1638, os delegados discutiram a questão e solicitaram a Nassau e ao Conselho da Companhia das Índias Ocidentais que baixassem um edital proibindo manifestações católicas e de judeus, "com suas velhacarias, trazendo vergonha à Igreja de Cristo". (ATAS DAS CLASSES, 1638, p. 26). As solicitações se repetiram, porém, Nassau e o Conselho preferiam a política de boa vizinhança. Segundo Barléu, Nassau defendia a "liberdade de consciência, porque era isso assunto divino e não cabia no domínio do juízo humano " (BARLÉU, 2018, p. 101). Seguia a política vigente na Holanda das boas relações entre calvinistas e judeus. Barléu, em epigrama homenageando Menasseh Ben Israel, Rabino de Amsterdam, escreveu: "Embora pensemos diferente/Vivemos com amigos em Deus. /Essa é a expressão mais alta de minha fé. / Acredite nisso, Menasseh. /Assim como eu sou filho de Cristo, /Você também é filho de Abraão." (NADLER, 2018, p. 73).

Oficialmente havia liberdade de consciência no Brasil holandês, porém nas relações cotidianas entre calvinistas holandeses e judeus luso-brasileiros ocorreram conflitos, as vezes 
motivados por disputas entre negociantes. A Companhia das Índias Ocidentais detinha o monopólio dos produtos coloniais e não perdoava os devedores, mercadores e senhores de engenhos luso-brasileiros em dificuldades financeiras. Na correspondência do Conselho dos XIX e do Conde Nassau a cobrança de dívidas aparece com frequência, indicando que “escravos, bois e partes do engenho não podem ser confiscados” (XAVIER,2011, p.177). O mercador judeu Moisés Abendana, em 1642, não suportando as pressões em decorrência de "suas dívidas comerciais na praça de Recife suicidou-se e as autoridades impediram a celebração de seu sepultamento ritual e o corpo do insolvente foi exposto numa forca para desacreditar a nação judaica” (LIPINER,1992, p.167). O filantropo judeu Duarte Silveira pagou as dívidas e providenciou um sepultamento digno, ao mercador Abendana.

Padre Vieira em 1647 foi embaixador de Portugal nos Países Baixos, fato que deve ter pesado em sua mudança de opinião, Padre Vieira passou a defensor dos judeus: “era preciso voltar à pátria os judeus foragidos...lhes devia permitir o culto público de sua religião do mesmo modo que em Roma, sede da Cristandade" (NADLER, 2018, p. 139). Defendeu, junto a monarquia que o dinheiro dos judeus voltasse as terras lusitanas. Vieira manteve conversações teológicas com o Rabino Menasseh Ben Israel, da Sinagoga Portuguesa de Amsterdam. Ao que parece, a diversidade religiosa e a liberdade de consciência vigente na Holanda, ou razões materiais, proporcionou ao Padre uma nova visão, frente ao exclusivismo católico dos ibéricos.

A relação amistosa e mercantil entre os calvinistas da Companhia das Índias Ocidentais no Brasil holandês e os judeus perdurou até o fim do período. No acordo de rendição assinado por F. Barreto representando as forças ibéricas e pelo lado holandês W. Schonenborch e H. Haecks ficou garantido que "Os judeus sephardim e askenazim que aqui se encontram três meses de permanência no Brasil, para liquidarem seus negócios, disporem de seus bens, e serem acomodados nas embarcações que os levassem para fora do País” (MELLO, 1979, p. 48).

A expulsão dos invasores desestruturou a Igreja Reformada no Nordeste. Na Holanda, a situação dos calvinistas e dos judeus preocupavam clérigos e parentes. Nas atas foi registrado: "em novembro de 1649 não houve assembleias classicais, existe poucos predicantes e as atuais condições do país não o permitem" (ATAS DAS CLASSES, 1649, p. 51). Vencidos os holandeses em 1654, A Igreja Reformada no Brasil foi extinta, bem como a Sinagoga Zur Israel. A liberdade religiosa no Brasil apenas aconteceria em 1889, com a Proclamação da República. 


\section{CONSIDERAÇÕES FINAIS}

A Igreja Católica era um instrumento de manutenção da unidade do império lusitano. A Península Ibérica e seus domínios de além-mar na Idade Moderna viviam uma realidade conflituosa, um campo religioso em permanente disputa, no que pese o velho tronco abraâmico onde se nutriram da mesma seiva judeus, católicos e protestantes. A ortodoxia rimava com monarquia e a heterodoxia protestante e o judaísmo rimavam com traição, subversão política. A intolerância religiosa era parte das disputas políticas.

Os cristãos-novos, mercadores e senhores de engenho que habitavam o Brasil nos primórdios do período colonial montaram redes de comércio com os flamengos calvinistas, bem como redes de solidariedade e estratégias de enfrentamento semelhantes contra o inimigo comum, que era a Igreja Católica ou o Tribunal do Santo Oficio. Perseguiam-se os suspeitos de desvios morais, porém essencialmente judaizantes e protestantes, que ameaçavam a unidade da cristandade. A narrativa das práticas inquisitoriais propagou-se nos países de maioria protestante, acusando o Catolicismo de tirania, que perseguia judeus e reformados.

Na recomposição de suas identidades na Terra Brasilis, em território católico, judeus, cristãos-novos e protestantes desenvolveram afinidades eletivas e práticas comuns, a exemplo da adoção de nomes lusitanos, a abjuração da fé em mesa inquisitorial e a manutenção secreta de rituais, a exemplo da leitura do texto bíblico, proibido em linguagem pela Igreja Católica. Vários cristãos-novos permaneceram com suas práticas judaicas realizadas, particularmente, em suas casas. As sinagogas foram denunciadas nas Visitações, bem como a leitura da Torá.

A Sinagoga Portuguesa de Amsterdam, fundada no século XVII, por judeus expulsos da Península Ibérica, é uma prova das relações entre sefarditas e protestantes nos Países Baixos. Os termos português e judeu eram sinônimos nos Países Baixos no período. Várias pessoas, na América Portuguesa, denunciadas pela Inquisição, circularam em Flandres, Antuérpia ou Amsterdam, realizando seus negócios e frequentando livremente as congregações religiosas. Durante o domínio holandês no Nordeste do Brasil houve uma relativa tolerância religiosa, que permitiu a construção de Sinagogas Judaicas e templos da Igreja Reformada.

\section{REFERÊNCIAS BIBLIOGRÁFICAS}

ALVES, Rubem. Protestantismo e Repressão. São Paulo: Ática, 1979.

ANTUNES, Cátia. Lisboa e Amesterdão 1640-1705. Um caso de Globalização na História Moderna. Lisboa: Livros Horizontes, 2009. 
ASSIS, Ângelo Faria de. Macabeias da Colônia Criptojudaismo feminino na Bahia. São Paulo: Alameda, 2012.

ATAS dos Synodos e Classes. In SOUTO MAIOR, Pedro. A Religião Reformada no Brasil século XVII Durante o Domínio Holandês. Rio de Janeiro. IHGB v.II,1914. p.707-780.

BAERS, J. Olinda Conquistada. In SILVA; Leonardo Dantas. (org.) 350 Anos da

Restauração Pernambucana. Recife. C. Editora Pernambucana, 2004.

BARLÉU, Gaspar. História do Brasil sob o Governo de Maurício de Nassau (1636-1644). Recife: CEPE, 2018.

BETHENCOURT, Francisco. História das Inquisições. Portugal, Espanha e Itália século XV- XIX. São Paulo: Companhia das Letras,2000

BOER, Harm Den. Spanish and Portuguese. Editions from the Northern Netherlands. Madrid and Lisbon: Studia Rosenthaliana,1988.

BRAGA, Isabel M.R; MENDES, Drummond. Os Estrangeiros e a Inquisição Portuguesa. Lisboa: HUGUIN Editores, 2002.

BROUVEZ, C. Inquisição Espanhola. Leyden: Biblioteca da Universidade de Leiden, 1556.

CALLADO Frei Manoel. Valeroso Lucideno e Triumpho da Liberdade, Lisboa, Officina de Domingos Carneiro, 1668.

CALVINO, Juan. Las Institutions de La Religion Cristiana. Buenos Aires: Editorial Aurora, 1958.

CHARTIER, R. A História cultural: entre práticas e representações. Portugal: Difel, 2002.

CRESPIN, Jean. A Tragédia da Guanabara. Rio de Janeiro, Typo-Lith Pimenta de Mello \&.C, 1917.

DELLON, C. Le Inquisition de Goa, La Relation de Charles Dellon. Paris: Editions Chandeigne, 1997.

Denunciações e Confissões de Pernambuco 1593-1595. Recife: FUNDARTE,1984.

EYMERICH, Nicolau. Manual dos Inquisidores. Diretorium Inquisitorum. Rio de Janeiro: Rosa dos Tempos, 1993.

GALINDO, Marcos (org.) Episódios Baianos Documentos para a História do período holandês na Bahia. Recife: NÉCTAR, 2010.

GARRISON, Janine. Protestants Du Midi 1559 - 1598. Toulouse: Editons Privat, 1991. 
GUZMAN, D. J. de V. A Jornada del Brasil In: MIRAFLORES M.y SALVA, D.

M..Colecion de Documentos Ineditos para a História de Espanha. Biblioteca da D. A.

Canoval Del Castilo. Madri: Imprenta dela vida de Calera, 1870.

ISRAEL, Jonathan I. The Dutch Republic Its Rise, Greatness, and Fall 1477-1806. Oxford: Oxford University Press, 1998.

ISRAEL, Menasseh Ben. Origen de los Americanos Esto es Esperanza de Israel. Madri: Libreria de Santiago Perez Junqueira, 1881.

KAPLAN, Yosef. Do Cristianismo ao Judaísmo A história de Isaac Oróbio de Castro. Rio de Janeiro.Imago.2000.

KIBUUKA, Brian. Prefácio ao Antigo Testamento uma perspectiva cristã. São Paulo: Fonte Editorial, 2019.

LAET Johannes de. História da Companhia das Índias Ocidentais. Rio de Janeiro. Annaes da Biblioteca Nacional, 1912.

LÉRY, Jean de. Viagem à Terra do Brasil. Belo Horizonte Itatiaia: São Paulo; EDUSP, 1980.

LIPINER, Elias. Izaque de Castro O Mancebo que Veio Preso do Brasil. Recife, Massangana,1992.

Livro De Cartas De S. Magestade. 1692.Cota 51 V-48, p.12. Lisboa, Biblioteca da Ajuda.

LOSE, Alicia; PAIXÃO, D. Gregório OSB; OLIVEIRA, Anna Paula. SANCHES, Gersica Alves. Dietário (1532-1815): Mosteiro de São Bento da Bahia, Salvador. EDUFBA, 2009.

MACEDO, Janete R. Digressões Da Capitania De São Jorge Dos Ilhéus Na Inquisição do Santo Oficio: 1591-1620. In: LEAL, Graça; MOREIRA, R.; CASTELLUCCI, W. Capítulos de História da Bahia Novos Enfoques Novas Abordagens.São Paulo: UNEB-Annablume, 2009.

MAGAlHÃES, Pablo Iglesias. A Guerra Defensiva na Capitania da Bahia (1625-1654). In Revista do Instituto Arqueológico, Histórico e Geográfico Pernambucano.no.69, Recife.2016

MARQUES, Guida. As Ressonâncias da Restauração da Bahia (1625) E A Inserção da América Portuguesa na União Ibérica. In: HERNANDEZ, Santiago Martinez. Governo, Política e Representações do Poder no Portugal Habsburgo e nos seus Territórios Ultramarinos (1581-1640). Lisboa: Centro de História de Além-Mar, 2011.

MEA, Elvira Cunha de Azevedo. Inquisição e Sociedade (séculos XVI e XVII). In: SILVA, Marco Antonio N.; SEVERS, Suzana Maria Santos. Estudos Inquisitoriais história e historiografia. Cruz das Almas: Editora UFRB, 2019. 
MELlO NETO, José Gonsalves. Tempo dos Flamengos. São Paulo: Livraria José Olympo Editora, 1947.

MELLO, José A. Gonsalves de. A Rendição dos Holandeses. Recife: Editora UFPE, 1979.

MENDONÇA, Heitor Furtado. Denunciações da Bahia, Rio de Janeiro. Biblioteca Nacional.1929.

NADLER, Steven. Menasseh Ben Israel. London: Yale University Press, 2018.

NOVINSKY, Anita W. Análise Crítica da Historiografia Sobre a Inquisição. In: SILVA, Marco Antonio N.; SEVERS, Suzana Maria Santos. Estudos Inquisitoriais história e historiografia. Cruz das Almas: Editora UFRB, 2019.

NOVINSKY, Anita W. Cristãos Novos na Bahia. São Paulo: Perspectiva, 1972.

NOVINSKY, Anita W. Inquisição: Prisioneiros do Brasil séculos XVI A XIX. São Paulo: Perspectiva, 2009.

PÉREZ, J. M. S. Filipe III e a ameaça neerlandesa no Brasil: medos globais, estratégia real e respostas locais. In: WIESEBRON, M. in de Nederlandse archieven $\mathbf{O}$ Brasil em arquivos Holandeses. Mauritiana vol.5. Leiden: University Press, 2013.

PROCESSO de João de Bolés, Biblioteca Nacional. Rio de Janeiro.XXV.1903-1904.

PROCESSO 2320 de Salvador Maia. Inquisição de Lisboa. Arquivo da Torre do Tombo.

PROCESSO 03618 de Alberto Jacobo Inquisição de Lisboa Arquivo da Torre do Tombo.

REGO, R. O Processo de Damião de Góes na Inquisição. Lisboa: Assírio e Alvim,2007.

RIBEIRO, Eneida Beraldi. Bento Teixeira e a "Escola de Satanás". O Poeta, que teve a prisão por recreação, a solidão por companhia e a tristeza por prazer. Tese (Doutorado em História) -Universidade de São Paulo, São Paulo, 2006.

SCHAMA, Simon. O Desconforto da riqueza: a cultura holandesa na época do ouro. São Paulo. Companhia das Letras. 1992.

SCHWARTZ, Stuart; PECORA, Alcir. As Excelências do Governador. O Panegírico fúnebre a D. Afonso Furtado, de Juan Lopes Serra Bahia, 1676. São Paulo. Companhia das Letras. 2002

SHALKWIJK, F. L. Igreja e Estado no Brasil Holandês. São Paulo: Vida Nova. 1989.

SILVA, Elizete da. Representações Protestantes Sobre a Inquisição. In: SILVA, Marco Antonio N.; SEVERS, Suzana M. Santos. Estudos Inquisitoriais história e historiografia. Cruz das Almas: Editora UFRB, 2019. 
SILVA, Elizete da. Protestantes na Terra da Promissão: entre Deus e Mamom. In: ALMEIDA, Vasni; SANTOS, Lyndon A.; SILVA, Elizete da. Os 500 Anos da Reforma Protestante no Brasil um debate histórico e historiográfico. Curitiba: CRV, 2017.

SILVA, Emãnuel L. Souza. "Juntos à Forca": a Família Lopes e a visitação do Santo Oficio à Bahia (1591-1593). Rio de Janeiro: APED, 2013.

SIQUEIRA, Sonia. Confissões da Bahia. 1618-1620. João Pessoa: Idéia, 2011.

SOUZA, Grayce Mayre Bomfim. Para Remédio das Almas: Comissários, Qualificadores e Notários da Inquisição Portuguesa na Bahia Colonial. Vitória da Conquista: Ed. UESB, 2014.

STRUM, Daniel. O Comércio do Açúcar Brasil, Portugal e Países Baixos. (1595-1630). Rio de Janeiro: Fundação Odebrecht. Verbal Editores. 2012.

TAVARES, Luís H.D. História da Bahia. São Paulo: UNESP; Salvador: EDUFBA, 2001.

TEENSMA, B. N. O Inaceitável comportamento do Predicante da Companhia das Índias Ocidentais Daniel Schagen. In WIESEBRON, Marianne. In de Nederlandse archieven O Brasil em arquivos Holandeses. Mauritiana vol.5. Leiden. University Press, 2013.

VAINFAS, Ronaldo. Confissões da Bahia: Santo Oficio da Inquisição de Lisboa; São Paulo: Cia das letras, 1997.

VARNHAGEN, F. A. História das Lutas com os Holandeses no Brasil desde 1624-1625. Lisboa:(s e), 1872.

VIEIRA, A. A invasão holandesa na Bahia. Salvador: Progresso, 1957.

VIEIRA, Hugo Coelho; GALVÃO, Nara Neves Pires; SILVA, Leonardo Dantas (org.) Brasil Holandês História, Memória e Patrimônio Compartilhado. São Paulo: Alameda, 2012.

WEBER, M. A ética protestante e o espírito do capitalismo. Rio de Janeiro: Pioneira, 1967.

XAVIER, Lúcia W. Companhia das Índias Ocidentais Velha. Número de Chamada 1.05.01.01. In WIESEBRON, Marianne. Brazilie in de Nederlandse archieven O Brasil em arquivos Holandeses. Mauritiana vol.4.Leiden. University Press, 2011. 